anales de psicología / annals of psychology

2020, vol. 36, $\mathrm{n}^{\circ} 1$ (january), 56-63

https://doi.org/10.6018/analesps.356051
(C) Copyright 2020: Editum. Servicio de Publicaciones de la Universidad de Murcia. Murcia (Spain) ISSN print edition: 0212-9728. ISSN on line edition (http://revistas.um.es/analesps): 1695-2294.

On line edition License Creative Commons 4.0: BY-NC-ND

\title{
Content and format preferences of a depression prevention program: A study in perinatal women
}

\author{
Jorge Osma ${ }^{1 *}$, Carlos Suso-Ribera ${ }^{2}$, Verónica Martínez-Borba ${ }^{2}$, and Alinne Z. Barrera ${ }^{3}$ \\ 1 Universidad de Zaragoza \& Instituto de Investigación Sanitaria de Aragón (Spain) \\ 2 Universitat Jaume I, Castellón (Spain) \\ 3 Palo Alto University, Palo Alto, CA (USA)
}

\begin{abstract}
Título: Estudio de preferencias sobre contenidos y formatos para un programa de prevención de la depresión: un estudio en mujeres perinatales.

Resumen: Antecedentes: este trabajo explora las diferencias étnicas en preferencias de contenido y formato de un programa preventivo de depresión perinatal. Método: participaron 163 mujeres en etapa perinatal $(66.9 \%$ embarazadas; $33.1 \%$ en el posparto) que se identificaron como latinas $(45.4 \%)$ y no latinas $(64.6 \%)$. Resultados: el formato preferido fue individual y en persona para todos los contenidos. Solo cuando el contenido tenía que ver con la comunicación de pareja, considerarían incluir a la pareja. No se encontraron diferencias significativas en función de la etnia en las preferencias de formato. En cuanto al contenido, las mujeres prefirieron "información sobre el proceso de embarazo, incluyendo cambios físicos y psicológicos". Las mujeres no latinas mostraron una mayor preferencia por "realizar evaluaciones regulares sobre su estado emocional' en comparación a las latinas. Conclusiones: estos resultados deberían considerarse a la hora de diseñar futuros programas de prevención para la depresión perinatal y evidencian la necesidad de trabajar más en las intervenciones online si queremos que se valoren más favorablemente por las mujeres perinatales.
\end{abstract}

Palabras clave: Prevención; Tecnologías de la información y comunicación; Latina; Perinatal; Preferencias de tratamiento.

\section{Introduction}

Published reports on the global prevalence of perinatal depression suggest that we are currently facing an important mental health challenge. With respect to prenatal depression, global rates are between $6 \%$ and 38\%, with high prevalence rates in Western nations like Canada (20\%), England (31\%), and the United States (38\%; Field, 2011). Similarly, high prenatal incidence rates have been reported in Latin countries and territories, ranging from $16 \%$ to $30 \%$ in Mexico, the Dominican Republic and, in the United States, Puerto Rico (i.e., Lara et al., 2015). Unfortunately, the global rate of postpartum depression (PPD) is not any more encouraging. $9.3 \%$ of women residing in United States (Vesga-López et al., 2008) met criteria for PPD, compared to $13.3 \%$ of Mexican women (Lara et al., 2015) and 53\% of Dominican and Puerto Rican women (Zayas, Jankowski, \& McKee, 2003). Lower rates have been reported in Germany $(6 \%)$ and Spain $(8 \%)$, as well as in Belgium, Poland, and Italy (between 13$16 \%$; Grote et al., 2010). Given the global impact, countries ought to provide women with appropriate prevention and intervention programs that are easy to disseminate, widely ac-

* Correspondence address [Dirección para correspondencia]: Jorge Osma, Ph. D., Facultad de Ciencias Sociales y Humanas. Universidad de Zaragoza. C/ Ciudad Escolar s/n 44003 Teruel (Spain).

E-mail: osma@unizar.es

(Article received: 28-12-2018; revised: 6-3-2019; accepted: 12-4-2019)
Abstract: Background: this study investigated ethnic differences in the preferred content and delivery method of a depression prevention program for perinatal women. Method: participants were 163 pregnant $(66.9 \%)$ and postpartum (33.1\%) women. Women identified themselves as Latinas $(45.4 \%)$ or non-Latinas $(54.6 \%)$. Results: overall, women preferred individual and onsite therapy across contents. Only when the content was related to improving communication, they were willing to incorporate the partner. There were no ethnic differences in the preferred format. Regarding content, women preferred to receive "information on the pregnancy process including physical and psychological changes." Non-Latinas had a higher preference for "receiving regular check-ins on their emotional state" than Latinas. Conclusions: these results should be considered when developing future perinatal depression prevention programs and evidence that work needs to be done if we want online interventions to be viewed more favorably by perinatal women.

Keywords: Depression prevention; Information and Communication Technologies; Latina; Perinatal; Treatment preferences.

cepted, and adjusted to the women's daily lives and needs (Vázquez, Blanco, Torres, Otero, \& Hermida, 2014).

Pregnant and postpartum women are interested in mental health prevention and intervention programs. A recent study demonstrated that $85 \%$ of pregnant women were interested in psychological approaches that helped them to prepare for motherhood, such as methods to improve their well-being (Dimidjian \& Goodman, 2014). Also, a majority of childbearing age women agreed/strongly agreed that prenatal $(79.2 \%)$ and postnatal $(88.5 \%)$ mental health screening should be routinely conducted (Kingston et al., 2014). Despite the overwhelming endorsement, mental health services remain underutilized and most women do not benefit from any type of formal psychological support during the perinatal period (Hewitt \& Gilbody, 2009), thus suggesting that barriers to maternal mental health services need to be identified and addressed.

Some mothers experience barriers like difficulties in transportation and feelings of guilt and stigma about being depressed (i.e., Byatt, Simas, Lundquist, Johnson, \& Ziedonis, 2012), barriers which have been argued to decrease with the use of alternate options such as technology-based resources (e.g., online treatment; Donker, Cuijpers, Stanley, \& Danaher, 2015). However, while online treatments appear to be well accepted in general (Maloni, Przeworski, \& Damato, 2013), perinatal women have consistently preferred face-to-face interventions as the treatment format of choice (Dimidjian \& Goodman, 2014) and only a small proportion 
of women $(1.5 \%)$ appear to prefer web-based Internet support (Goodman, 2009) and would rather receive treatment individually than in group (Goodman, 2009).

What previous investigations suggest is that treatment preferences should not be ignored in the context of perinatal depression, as they might have important implications for help-seeking behaviors and related barriers, utilization of psychological resources, and access to care (Mallou, Boubeta, \& Cueto, 2003; Supplee, Parekh, \& Johnson, 2018). Unfortunately, however, important shortcomings in the existing literature make the current conclusions limited and difficult to generalize. Specifically, the preferences are rarely explored together in the same study and cultural differences are rarely investigated, thus, leading to inconclusive results. In sum, while the study of treatment preferences might be important when developing new psychological interventions for perinatal women, there is a need to combine all the aforementioned elements together in one study, while accounting for ethnic differences. Therefore, this investigation aims to examine depression prevention intervention preferences (online vs. onsite, individual vs. group, and alone vs. with their partner) among women who identify as Latinas compared to non-Latinas across four different treatment content areas. Although this is a cross-sectional preliminary study, we expected to replicate some of the findings reported previously. More specifically, we hypothesized that, while some participants would accept online treatment options, onsite treatment would remain a higher order preference. Additionally, we anticipated that individual treatment would be preferred over group interventions and that intervention content addressing general information to prepare women for motherhood would be preferred over a more targeted program on depression prevention due to the stigma associated with mental health. Finally, we hypothesized that ethnic differences, if evident, would be modest with the direction of such differences to be analyzed in an exploratory manner.

\section{Methods}

\section{Participants and procedures}

Google AdWords campaigns were used to advertise and recruit perinatal women interested in providing information about their sociocultural, emotional, and pregnancy experiences. Women who were at least 18 years old, currently pregnant or within one year postpartum, and able to read English or Spanish were invited to complete an anonymous and voluntary online survey. Data for participants in this study were recruited via the Internet using an online survey available in English and Spanish between October 16, 2014 and March 30, 2015. Of eligible women $(n=1,805), 509$ consented to participate. Of these, 81 did not indicate their ethnic identity and 265 failed to provide data on the content format preferences outcome variables, so they were excluded from the study analysis. The final sample analyzed in this report was comprised of 163 perinatal women with a mean age $=28.36$ years $(S D=6.20)$. A majority were pregnant $(66.9 \%)$ and almost equally identified as Latina $(45.4 \%)$ or non-Latinas $(54.6 \%)$. There were no group differences in education level $\left(\chi^{2}(1,163)=0.93, p=.418\right)$, marital status $\left(\chi^{2}\right.$ $(1,163)=2.51, p=.113)$, or number of children $(t=1.29$, $p=.200)$. Countries of origin were diverse and, therefore, categorized into representative groups. Women who identified themselves as Latinas were mostly from South America $(n=55)$. The remaining Latina participants identified their region or country of residence as Caribbean $(n=6)$, Central America $(n=4)$, Spain $(n=2)$, or other $(n=6)$. On the other hand, the majority of non-Latinas were originally from North America $(n=40)$. Other regions included South America $(n=12)$, South and South-East Asia $(n=16)$, Central and South Africa $(n=8)$, and other $(n=7)$. Almost all Latinas completed the study survey in Spanish $(90.5 \%)$, while the majority of non-Latinas chose to complete the study survey in English (84.3\%). See Table 1 for their demographic characteristics. The Institutional Review Board at the sponsoring university approved all study procedures.

Table 1. Sociodemographic characteristics of Latina and non-Latina pregnant and postpartum women.

\begin{tabular}{|c|c|c|c|c|}
\hline & $\begin{array}{l}\text { Latina } \\
n=74\end{array}$ & $\begin{array}{c}\text { Non-Latina } \\
n=89\end{array}$ & $t / \chi^{2}$ & $p$ \\
\hline$\overline{A g e^{\mathrm{a}}}$ & $27.23(5.99)$ & $29.29(6.24)$ & 2.13 & .035 \\
\hline Number of children & $1.92(0.89)$ & $2.15(1.28)$ & 1.29 & .200 \\
\hline Perinatal period & & & 12.35 & $<.001$ \\
\hline Pregnant & $60(55.0)$ & $49(45.0)$ & & \\
\hline Postpartum & $14(25.9)$ & $40(74.1)$ & & \\
\hline Marital status ${ }^{\mathrm{b}}$ & & & 2.51 & .113 \\
\hline Married/Cohabitating & $58(42.6)$ & $78(57.4)$ & & \\
\hline Single/Divorced & $16(59.3)$ & $11(40.7)$ & & \\
\hline Socioeconomic status ${ }^{\mathrm{b}}$ & & & 4.60 & .032 \\
\hline Middle & $61(42.4)$ & $83(57.6)$ & & \\
\hline Low & $13(68.4)$ & $6(31.6)$ & & \\
\hline Educational level & & & 0.93 & .334 \\
\hline$<12$ years & $16(53.3)$ & $14(46.7)$ & & \\
\hline$>12$ years & $58(43.6)$ & $75(56.4)$ & & \\
\hline Language ${ }^{b}$ & & & 90.46 & $<.001$ \\
\hline English & $67(90.5)$ & $14(15.7)$ & & \\
\hline Spanish & $7(9.5)$ & $75(84.3)$ & & \\
\hline
\end{tabular}

\section{Instruments}

The survey was created ad hoc for this study and have included the following sections:

Demographic Characteristics: Participants provided information on their age, language preference, perinatal status, number of children, country of residence, racial background, marital status, employment status, socioeconomic status, and educational level.

Program Content: Four content areas were presented to participants based on mental health guideline recommendations related to depression prevention that target the need 
for ongoing assessment of depression (content a; Haga, Drozd, Brendryen, \& Slinning, 2013), the most common components included in programs to prepare for motherhood (contents b and c; O'Mahen et al., 2014; Parker, Dmitrieva, Frolov, \& Gazmararian, 2012), and recommendations for healthy communication and social support from partners (content d; Elsenbruch et al., 2007). Each content area was framed as follows:

- Content a. Conducting regular check-ins on their emotional state during pregnancy and postpartum using a questionnaire (depression prevention content).

- Content b. Providing information about the pregnancy process, including physical and psychological changes, as well as information about the development of the baby (preparing for motherhood content).

- Content c. Providing information about the health and care of their baby in the first year postpartum and later on when raising their child (preparing for motherhood content).

- Content $d$. Providing information and tips on how to communicate with their partner to increase collaboration and support during pregnancy and postpartum (depression prevention content).

Intervention Preferences: A set of questions to assess preferred methods of delivery (e.g., "Would you like to receive regular check-ins on your emotional state during pregnancy and postpartum using a questionnaire?") and preferred format (e.g., online vs. onsite, individual vs. group, and alone vs. with their partner) were created for each content area (e.g., "Individually, on my cell phone using an application developed by psychologists" or "In a group, with other pregnant women in a Health Center and a psychologist/health professional"). In total, eight format preferences were presented to participants. All preferences were introduced with the sentence, "How would you like to receive this resource or information." Each preference option was categorized into three dichotomous groups (online vs. onsite, individual vs. group, alone vs. with your partner). Content areas were introduced with the sentence, "Where would you like to receive this resource or information." For a full description of the questions and how they were categorized refer to Table 2.

Table 2. Format preferences and their corresponding classification

\begin{tabular}{|c|c|c|c|}
\hline How would you like to receive the [insert one of the four contents] content? & $\begin{array}{l}\text { Individual/ } \\
\text { Group }\end{array}$ & $\begin{array}{l}\text { Online/ } \\
\text { On site }\end{array}$ & $\begin{array}{l}\text { Alone/ } \\
\text { Partner }\end{array}$ \\
\hline 1. Individually, in a Health Center or & Individual & On site & Alone \\
\hline n (computer) developed by psychologists & Individual & Online & Alone \\
\hline 3. Individually, on my cell phone using an application developed by psychologists & Individual & Online & Alone \\
\hline 4. With my partner, in a Health Center or with a psychologist & Individual & On site & With partner \\
\hline 5. With my partner, at home through an online program (computer) devel & Individual & Online & With partner \\
\hline 6.With my partner, on my cell phone using an application developed by psychologis & Individual & Online & With partner \\
\hline 7. In a group, with other pregnant women in a Health Center and a psychologist/health professional & Group & On site & Alone \\
\hline $\begin{array}{l}\text { 8. In a group, with my partner and other couples in a Health Center and a psychologist/health pr } \\
\text { fessional }\end{array}$ & & On site & With partner \\
\hline
\end{tabular}
fessional

Note: The table shows all study questions and how they were categorized (online vs. onsite, individual vs. group, alone vs. with your partner). Items 1 to 8 represent the answers about preferences for each question.

\section{Statistical analysis}

First, we investigated whether both groups (Latinas and non-Latinas) were similar demographically by means of a Student's $t$-test (for continuous variables) or a Chi-square test (for categorical variables). Second, a comparison between Latinas and non-Latinas' preferences for each of the proposed content areas was examined using a Chi-square test for group differences. A final analysis of independence was planned for each content type to calculate differences in format preferences (online vs. onsite, individual vs. group, and alone vs. with their partner) across the two ethnic groups (e.g., format preference independent of ethnic group for a given content). However, because we observed that the sample was segmented into two arguably different groups (pregnant vs postpartum), we conducted an additional analysis to explore content preferences as a function of the perinatal period of participants. All analyses were completed with the Statistical package SPSS version 22 (IBM Corp, 2013).

\section{Results}

\section{Sample characteristics}

As seen in Table 1, an examination of differences across the two ethnic groups revealed that Latinas were younger than non-Latinas $(t=2.13, p=.035,95 \% \mathrm{CI}=0.15,3.97)$, more likely to be pregnant $\left(\chi^{2}(1,163)=12.35, p<.001\right)$, and perceived their socioeconomic status as lower $\left(\chi^{2}(1,163)\right.$ $=4.60, p=.032$ ).

\section{Intervention content preferences}

For each of the four content areas, preference differences were examined between Latinas and non-Latinas (i.e., if the proportion of women who would like that content to be included in a depression intervention program for perinatal women was different across ethnic groups). No statistical differences were revealed for content areas $\mathrm{b}$ to $\mathrm{d}$, indicating 
similar levels of interest irrespective of ethnic background (see Figure 1). The data revealed a higher interest in regular check-ins on emotional state during the perinatal period among non-Latinas $\left(\chi^{2}(1,163)=7.08, p=.008\right)$. Content $\mathrm{b}$ and $c$ (information about pregnancy and health care of the

a. Regular check-ins on my emotional state using a questionnaire

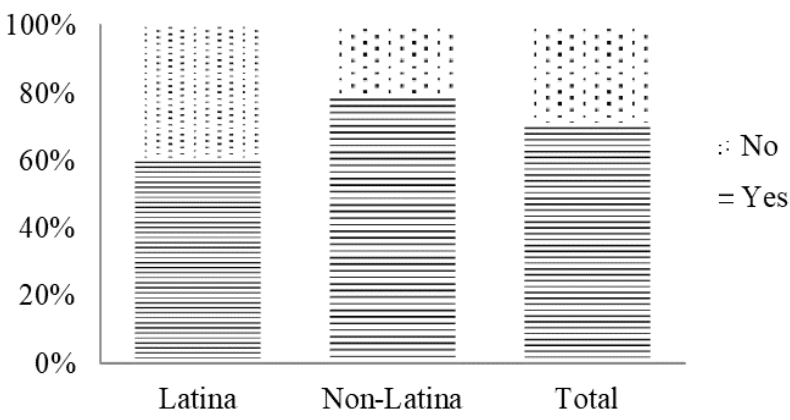

c. Receiving information on the health and care of your baby and later on raising your child

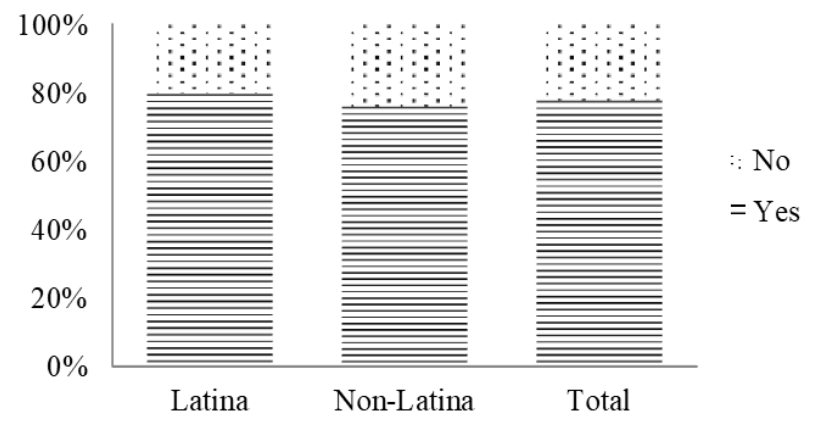

baby) were the most frequently preferred by all participants (73.6\% and $68.1 \%$, respectively). By contrast, the two remaining content areas, a and d (regular check-ins on their emotional state and communication with partner), were only selected by approximately $57 \%$ of the sample.

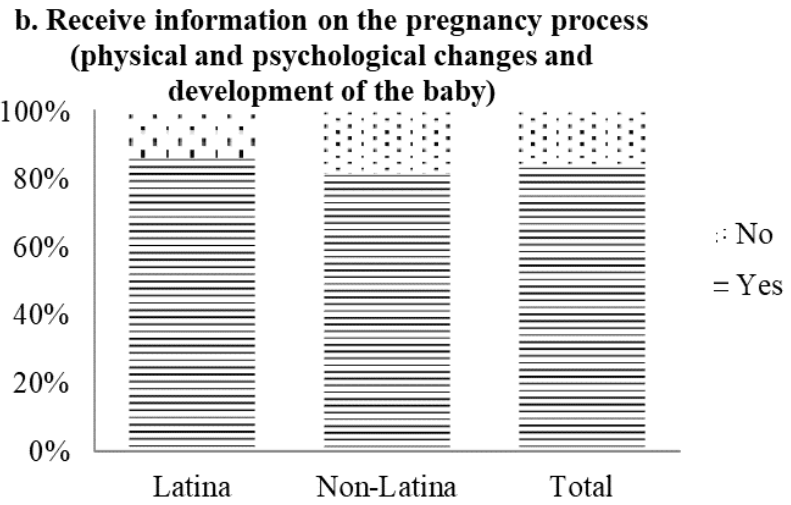

d. Receive information and tips on how to communicate with your partner to increase collaboration and support

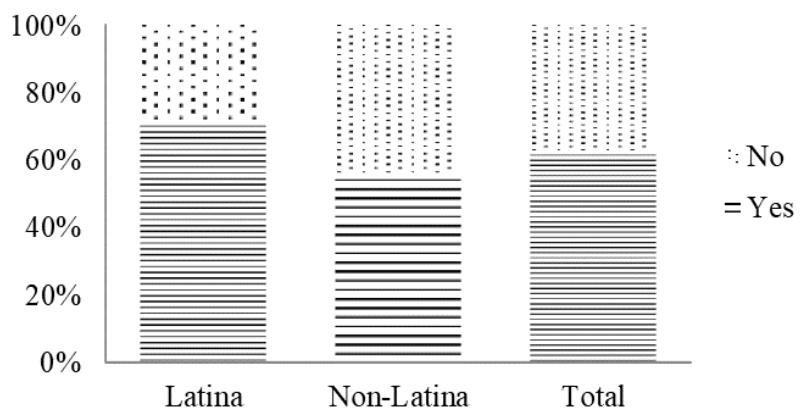

Figure 1. Intervention content area preferences of Latina and non-Latinas perinatal women.

Format preferences across ethnic groups and content areas

As seen in Table 3, there were no ethnic differences in the format preferences (individual vs. group, online vs. onsite, alone vs. with the partner) across the four content areas.
We found a non-significant trend in the proportion of Latina and non-Latina women who preferred to receive check-ins on their emotional state individually as opposed to in group $\left(\chi^{2}(1,106)=3.62, p=.057\right)$. That is, Latina women demonstrated a slight preference for participating in a group format when compared to non-Latinas.

Table 3. Preferences for intervention content area by format of delivery among perinatal Latina and non-Latina women

\begin{tabular}{|c|c|c|c|c|c|c|c|c|c|c|c|c|c|}
\hline & \multicolumn{4}{|c|}{$\begin{array}{c}\text { Regular check-ins on emotional } \\
\text { state... }\end{array}$} & \multicolumn{3}{|c|}{ Physical \& psychological changes... } & \multicolumn{3}{|c|}{ Health \& care of my baby... } & \multicolumn{3}{|c|}{ Communicate with my partner... } \\
\hline & $\begin{array}{c}\text { Latina } \\
n=40\end{array}$ & $\begin{array}{c}\text { non-Latina } \\
n=66\end{array}$ & $x^{2}$ & $p$ & $\begin{array}{c}\text { Latina } \\
n=49\end{array}$ & $\begin{array}{c}\text { non-Latina } \\
n=61\end{array}$ & $x^{2} p$ & $\begin{array}{c}\text { Latina } \\
n=38\end{array}$ & $\begin{array}{c}\text { non-Latina } \\
n=54\end{array}$ & $x^{2} \quad p$ & $\begin{array}{c}\text { Latina } \\
n=40\end{array}$ & $\begin{array}{c}\text { non-Latina } \\
n=35\end{array}$ & $\chi^{2} \quad p$ \\
\hline Individual vs group & & & 3.62 & .057 & & & 0.48 .488 & & & 0.26 .609 & & & 0.73 .393 \\
\hline Individual & 87.5 & 97.0 & & & 91.8 & 95.1 & & 88.9 & 92.1 & & 85.0 & 91.4 & \\
\hline Group & 12.5 & 3.0 & & & 8.2 & 4.9 & & 11.1 & 7.9 & & 15.0 & 8.6 & \\
\hline Online vs on site & & & $<.001$ & .999 & & & 0.39 .531 & & & 1.55 .213 & & & 0.14 .709 \\
\hline Online & 33.3 & 33.3 & & & 46.9 & 41.0 & & 31.6 & 44.4 & & 27.5 & 31.4 & \\
\hline On site & 66.7 & 66.7 & & & 53.1 & 59.0 & & 68.4 & 55.6 & & 72.5 & 68.6 & \\
\hline Alone vs partner & & & 1.99 & .159 & & & 1.54 .215 & & & 3.01 .083 & & & 0.10 .757 \\
\hline Alone & 70.0 & 81.8 & & & 59.2 & 70.5 & & 52.6 & 70.4 & & 55.0 & 51.4 & \\
\hline With the partner & 30.0 & 18.2 & & & 40.8 & 29.5 & & 47.4 & 29.6 & & 45.0 & 48.6 & \\
\hline
\end{tabular}

Note: Differences in sample sizes are reflective of not all individuals reporting a preferred format for all content areas. Values in the cells are percentages. 

Format preferences across content areas in the
whole sample

In addition to examining differences in format preferences as a function of ethnic group, we also conducted exploratory analyses to examine whether certain content areas were preferred in a particular format, irrespective of ethnic group (see Table 4). Our results indicated that the individual format $\left(\chi^{2}(3,383)=2.54, p=.468\right)$ and onsite delivery $\left(\chi^{2}(3\right.$,
382) $=4.76, p=.190$ ) were clearly preferred irrespective of the treatment content area. By contrast, the preference for receiving contents alone or with their partner was contentdependent $\left(\chi^{2}(3,383)=11.79, p=.008\right)$. Specifically, the post hoc analyses indicated that the company of the partner would be frequently selected when "receiving information and tips about how to communicate with the partner", but rare when "receiving regular check-ins on the emotional state" (adjusted, standardized residuals were 3.0 and -2.5 , respectively).

Table 4. Preferences for delivery format across content area in the whole sample

\begin{tabular}{|c|c|c|c|c|c|c|}
\hline & $\begin{array}{c}\text { Regular check-ins on emo- } \\
\text { tional state... } \\
n=106\end{array}$ & $\begin{array}{c}\text { Physical \& psychological } \\
\text { changes... } \\
n=110\end{array}$ & $\begin{array}{c}\text { Health \& care of my ba- } \\
\text { by... } \\
n=92\end{array}$ & $\begin{array}{c}\text { Communicate with my } \\
\text { partner... } \\
n=75\end{array}$ & $\chi^{2}$ & $p$ \\
\hline Individual vs group & & & & & 2.54 & .468 \\
\hline Individual & 93.4 & 93.6 & 90.2 & 88.0 & & \\
\hline Group & 6.6 & 6.4 & 9.8 & 12.0 & & \\
\hline Online vs on site & & & & & 4.76 & .190 \\
\hline Online & 33.3 & 43.6 & 39.1 & 29.3 & & \\
\hline On site & 66.7 & 56.4 & 60.9 & 70.7 & & \\
\hline Alone vs partner & & & & & 11.79 & .008 \\
\hline Alone & $77.4^{*}$ & 65.5 & 63.0 & $53.3^{*}$ & & \\
\hline With the partner & $22.6^{*}$ & 34.5 & 37.0 & $46.7^{*}$ & & \\
\hline
\end{tabular}

Note: Differences in sample sizes are reflective of not all individuals reporting a preferred format for all content areas. Values in the cells are percentages. ${ }^{*}$ Adjusted, standardized residuals are $>1.96$.

\section{Content preferences as a function of the perinatal period}

As reported in Table 5, postpartum women were more interested than pregnant participants in receiving "Regular check-ins on their emotional state" $\left(\chi^{2}(1,163)=4.19, p=.041\right)$. We did not find differences in the interest towards the remaining contents as a function of the perinatal period (all $p>.05)$.

Table 5. Content preferences as a function of the perinatal period in the whole sample

\begin{tabular}{|c|c|c|c|c|c|c|c|}
\hline & $\begin{array}{c}\text { Regular check-ins on } \\
\text { emotional state... } \\
n=106\end{array}$ & $\chi^{2} \quad p$ & $\begin{array}{c}\text { Physical \& psychological } \\
\text { changes... } \\
n=110\end{array}$ & $\chi^{2} \quad p$ & $\begin{array}{c}\text { Health \& care of my } \chi^{2} \quad p \\
\text { baby... } \\
n=92\end{array}$ & $\begin{array}{c}\text { Communicate with my } \\
\text { partner... } \\
n=75\end{array}$ & $\chi^{2} \quad p$ \\
\hline Perinatal period & & 4.19 .041 & & 0.61 .434 & 0.44 .509 & & 1.82 .178 \\
\hline Pregnancy & 66.1 & & 81.9 & & 76.0 & 66.3 & \\
\hline Postpartum & 81.5 & & 86.8 & & 80.8 & 54.9 & \\
\hline
\end{tabular}

Note: Differences in sample sizes are reflective of not all individuals reporting a preferred format for all content areas. Values in the cells are percentages.

\section{Discussion and Conclusion}

This study set out to examine depression prevention intervention content and delivery format preferences among a global sample of Latina and non-Latina perinatal women. Given the low utilization of psychological services among perinatal women (Bales et al., 2015) and the growing societal trend to rely on electronic information using mobile devices and computers (Internet World Stats, 2017), data from this study has the potential to influence the development of technology-based mental health resources that can be accessed by pregnant and postpartum women all around the world.

\section{Intervention content preferences}

The content options included in this study mainly focused on depression prevention and mood management (contents b and c) or on preparing for motherhood and parenting (contents a and d). All content options were acceptable by the perinatal women with a noticeable reduced preference for content related to depression prevention relative to content on preparing for motherhood. Our hypothesis, which was confirmed, was that the latter would be preferred, arguably due to the existence of maladaptive beliefs and misconceptions about depression and because of the negative stigma associated with perinatal depression (Byatt et al., 2012). In addition to the stigma, these results could also be explained by the characteristics of the content areas, which are focused on women's needs (emotional state screening and communication tips) instead of the babies' needs. 
While depression prevention content was considered less important than information on baby care, the least preferred content was that of "tips on how to communicate with your partner". Additionally, women frequently reported that they would prefer to participate in the treatment components without the company of their partner. These results are surprising despite the importance of social support during the perinatal period (Elsenbruch et al., 2007). One possible explanation is that mothers are not aware of the key role of social support during pregnancy and after delivery or maybe they believe that existing levels of communication and support from their partners are already in place. Another possibility is that certain parenting stereotypes or expectations may exist in the society, such as baby care being the sole responsibility of women, which might explain the prioritization of baby-care content over psychological and social ones (Georgas, Berry, van de Vijver, Kagitcibasi, \& Poortinga, 2006). Given this assumption, depression prevention plans should first tap into increasing women's interest in improving their psychological and social skills in order to contribute to their own well-being and, consequently, that of the baby.

\section{Format preferences}

In relation to ethnic differences, we had hypothesized that differences in preference between Latinas and NonLatinas, if present, would be very modest. Indeed, our study revealed that preferences were comparable across the two ethnic groups. Some studies have reported ethnic differences in treatment preferences (pharmacological vs. psychotherapy; Dimidjian \& Goodman, 2014; Goodman, 2009) type of health professional (Kingston et al., 2014), or type of setting (O'Mahen \& Flynn, 2008). However, to the best of our knowledge, none of the previous published reports investigated the interplay between content, format, and ethnicity. What our results suggest is that Latina and non-Latina perinatal women tend to agree about content and format preferences of prevention programs for perinatal depression. Specifically, all perinatal women preferred to receive a depression prevention program individually, onsite, and principally alone, regardless of ethnic identity. These results are similar to those reported by Goodman (2009) who found a clear preference for individual psychotherapy $(72.5 \%)$, which is usually delivered onsite and alone with the mental health professional.

An interesting finding in the present study was that group delivery format was rarely listed as preferred by perinatal women. The use of a group intervention format has multiple advantages for public and private health systems, which make it a very frequent delivery, format in clinical and research settings (Ickovics et al., 2011). However, in light of our results, this format could function as an initial barrier to participation, adherence, and maintenance of pregnant and postpartum women in a depression prevention program, and should be explored and discussed whenever an intervention is proposed. By aligning the delivery format with the moth- er's preferences or by changing some misconceptions about group format delivery, we might be able to reduce the barriers associated with depression prevention treatments.

As hypothesized, perinatal women showed a preference for onsite delivery format. Other studies have found the same results (Goodman, 2009). These findings remain speculative at this point given that perinatal women may perceive onsite interventions with health professionals as the most common format of health service delivery. However, research suggests that there are still some concerns with regards to the use of eHealth resources, especially in relation to privacy and a lack of clarity over how eHealth works and the services it provides (Peeters, Krijgsman, Brabers, Jong, \& Friele, 2016).

An additional finding in the study was that postpartum women were more keen on receiving regular check-ins on their emotional state when compared to their pregnant counterparts. No more differences in content preference were revealed between pregnant and postpartum women. These results are interesting as they indicate that women experience different needs across the perinatal period. One possible explanation for these findings is that the focus of attention during check-ins is likely to change from pregnancy (mostly the mother's well-being) to the postpartum (mostly the newborn's well-being). However, research has shown that emotional distress in the postpartum is not infrequent (Patel et al., 2012; Vliegen, Casalin, \& Luyten, 2014), which might explain why more attention to the mother's emotional state is appreciated at this stage. Note, however, that this is merely hypothetical and further conclusions cannot be drawn from the present study results.

This is not the first study to explore women's opinions about information and communication technologies (ICT) in the context of perinatal care. So far, research has indicated an open attitude by perinatal women towards technology tools for maternal health and mental health (Osma, Barrera, \& Ramphos, 2016). While acknowledging this, when compared to onsite treatment and program options, the numbers are discouraging. Thus, as researchers and clinicians, we are urged to consider how to increase the willingness to consider online program options in perinatal care. Given the limited access and utilization of maternal mental health programs and resources, the open attitude of perinatal women towards online format, and the increased global use of the ICT in healthcare (Internet World Stats, 2017), efforts should be directed toward developing and effectively disseminating digital treatments for perinatal depression prevention in order to impact perinatal women worldwide.

This study has a number of limitations that must be taken into account. First, the sample is limited to women who are active Internet users and who already have a certain level of comfort using technology and accessing information electronically. Second, there was significant number of women who declined to participate or who discontinued participation just after registering, so the generalization of results should be viewed with caution. Third, we used a closed an- 
swer option system to facilitate participation and to reduce the burden associated with online data collection. A qualitative study would surely provide rich information, but the low participation rate obtained with the current version of the study protocol suggests that some strategies to encourage participation should be conducted (e.g., economic compensation). Despite these shortcomings, this study represents an important preliminary step towards understanding what perinatal women prefer in terms of mental health support.

To the best of our knowledge, no other investigation has specifically examined technology-based preferences among perinatal women or the intersection between preferred type of content and method of delivery. The use of ICT, especially online format and mobile applications is becoming a feasible alternative delivery format of prevention and treatment interventions for perinatal depression. While, perinatal women appear to be open to receiving depression prevention content using online and mobile technologies, our study evidenced that there is still a gap we need to bridge if we want

\section{References}

Bales, M., Pambrun, E., Melchior, M., Glangeaud-Freudenthal, N. M. C., Charles, M. A., Verdoux, H., \& Sutter-Dallay, A. L. (2015). Prenatal psychological distress and access to mental health care in the ELFE cohort. European Psychiatry, 30(2), 322-328. https://doi.org/10.1016/j.eurpsy.2014.11.004

Byatt, N., Simas, T. A. M., Lundquist, R. S., Johnson, J. V., \& Ziedonis, D. M. (2012). Strategies for improving perinatal depression treatment in North American outpatient obstetric settings. Journal of Psychosomatic Obstetrics and Gynecology, 33(4), 143-161. https://doi.org/10.3109/0167482X.2012.728649

Dimidjian, S., \& Goodman, S. H. (2014). Preferences and attitudes toward approaches to depression relapse/recurrence prevention among pregnant women. Behaviour Research and Therapy, 54, 7-11. https://doi.org/10.1016/j.brat.2013.11.008

Donker, T., Cuijpers, P., Stanley, D., \& Danaher, B. (2015). The Future of Perinatal Depression Identification Can Information and Communication Technology Optimize Effectiveness? In J. Milgrom \& A. Gemmill (Eds.) (Oxford, UK, pp. 240-255). John Wiley: WileyBlackwell.

Elsenbruch, S., Benson, S., Rücke, M., Rose, M., Dudenhausen, J., PincusKnackstedt, M. K., ... Arck, P. C. (2007). Social support during pregnancy: Effects on maternal depressive symptoms, smoking and pregnancy outcome. Human Reproduction, 3(1), 869-877. https://doi.org/10.1093/humrep/del432

Field, T. (2011). Prenatal depression effects on early development: A review. Infant Behavior \& Development, 34(1), 1-14. https://doi.org/10.1016/j.infbeh.2010.09.008

Georgas, J., Berry, J. ., van de Vijver, F., Kagitcibasi, C., \& Poortinga, Y. . (2006). Families across cultures: A 30-nation psychological study. Cambridge, United Kingdom: Cambridge University Press.

Goodman, J. H. (2009). Women's attitudes, preferences, and perceived barriers to treatment for perinatal depression. Birth, 36(1), 60-69. https://doi.org/10.1111/j.1523-536X.2008.00296.x

Grote, V., Vik, T., von Kries, R., Luque, V., Socha, J., Verduci, E., ... Koletzko, B. (2010). Maternal postnatal depression and child growth: A european cohort study. BMC Pediatrics, 10, 14-22. https://doi.org/10.1186/1471-2431-10-14

Haga, S. M., Drozd, F., Brendryen, H., \& Slinning, K. (2013). Mamma mia: a feasibility study of a web-based intervention to reduce the risk of postpartum depression and enhance subjective well-being. JMIR online interventions to be viewed more favorably by perinatal women. As mental health researchers and providers, we must consider these preferences when developing needed resources to address the global burden of perinatal depression.

Funding: This study was funded by the "Estancias de movilidad en el extranjero José Castillejo para jóvenes doctores 2014" grant from the Plan Estatal de Investigación Científica y Técnica y de Innovación 2013-2016 en I+D+I along with the Fulbright Commission [CAS14/00237-FMECD-ST-2014]; by the Gobierno de Aragón (Departamento de Innovación, Investigación y Universidad), and FEDER "Construyendo Europa desde Aragón." [S31_17D]; and Online recruitment was made possible by an award to Ricardo F. Muñoz, Ph.D. while at the Zuckerberg San Francisco General Hospital/University of California, San Francisco [Google AdWords grant].

Acknowledgements.- The authors thank all the women who shared their experiences of motherhood through their participation in this study.

Research Protocols, 2(2), e29. https://doi.org/10.2196/resprot.2659

Hewitt, C. E., \& Gilbody, S. M. (2009). Is it clinically and cost effective to screen for postnatal depression: A systematic review of controlled clinical trials and economic evidence. BJOG: An International Journal of Obstetrics and Gynaecology, 116(8), 1019-1027. https://doi.org/10.1111/j.1471-0528.2009.02148.x

IBM Corp. (2013). IBM SPSS Statistics for Windows, Version 22.0. Armonk, NY: IBM Corp.

Ickovics, J. R., Reed, E., Magriples, U., Westdahl, C., Schindler Rising, S., \& Kershaw, T. S. (2011). Effects of group prenatal care on psychosocial risk in pregnancy: Results from a randomised controlled trial. Psychology \& Health, 26(2), 235-250. https://doi.org/10.1080/08870446.2011.531577

Internet World Stats. (2017). Internet usage statistics. Retrieved August 27, 2018, from https://www.internetworldstats.com/

Kingston, D., McDonald, S., Tough, S., Austin, M.-P., Hegadoren, K., \& Lasiuk, G. (2014). Public views of acceptability of perinatal mental health screening and treatment preference: a population based survey. BMC Pregnancy and Childbirth, 14(1), 67. https://doi.org/10.1186/14712393-14-67

Lara, M. A., Navarrete, L., Nieto, L., Barba Martín, J. P., Navarro, J. L., \& Lara-Tapia, H. (2015). Prevalence and incidence of perinatal depression and depressive symptoms among Mexican women. Journal of Affective Disorders, 175, 18-24. https://doi.org/10.1016/j.jad.2014.12.035

Mallou, J. V., Boubeta, A. R., \& Cueto, E. G. (2003). Presentación de una Escala de Satisfacción con los Servicios Sanitarios de Atención Primaria. Psicothema, 15(4), 656-661. https://doi.org/10.1093/cercor/bhw319

Maloni, J. A., Przeworski, A., \& Damato, E. G. (2013). Web recruitment and internet use and preferences reported by women with postpartum depression after pregnancy complications. Archives of Psychiatric Nursing, 27(2), 90-95. https://doi.org/10.1016/j.apnu.2012.12.001

O'Mahen, H. A., \& Flynn, H. A. (2008). Preferences and Perceived Barriers to Treatment for Depression during the Perinatal Period. Journal of Women's Health, 17(8), 1301-1309. https://doi.org/10.1089/jwh.2007.0631

O’Mahen, H. A., Richards, D. A., Woodford, J., Wilkinson, E., McGinley, J., Taylor, R. S., \& Warren, F. C. (2014). Netmums: A phase II randomized controlled trial of a guided Internet behavioural activation treatment for postpartum depression. Psychological Medicine, 44(8), 1675- 
1689. https://doi.org/10.1017/S0033291713002092

Osma, J., Barrera, A. Z., \& Ramphos, E. (2016). Are Pregnant and Postpartum Women Interested in Health-Related Apps? Implications for the Prevention of Perinatal Depression. Cyberpsychology, Behavior and Social Networking, $19(6)$
https://doi.org/10.1089/cyber.2015.0549

412-415.

Parker, R. M., Dmitrieva, E., Frolov, S., \& Gazmararian, J. A. (2012). Text4baby in the United States and Russia: An opportunity for understanding how mHealth affects maternal and child health. Journal of Health Communication, 17(SUPPL. 1), 30-36. https://doi.org/10.1080/10810730.2011.649162

Patel, M., Bailey, R. K., Jabeen, S., Ali, S., Barker, N. C., \& Osiezagha, K. (2012). Postpartum Depression: A Review. Journal of Health Care for the Poor and Underserved, 23(2), 534-542. https://doi.org/10.1353/hpu.2012.0037

Peeters, J. M., Krijgsman, J. W., Brabers, A. E., Jong, J. D. De, \& Friele, R. D. (2016). Use and Uptake of eHealth in General Practice: A CrossSectional Survey and Focus Group Study Among Health Care Users and General Practitioners. JMIR Medical Informatics, 4(2), e11. https://doi.org/10.2196/medinform. 4515

Supplee, L. H., Parekh, J., \& Johnson, M. (2018). Principles of Precision Prevention Science for Improving Recruitment and Retention of Participants. Prevention Science, 19(5), 689-694. https://doi.org/10.1007/s11121-018-0884-7

Vázquez, F. L., Blanco, V., Torres, Á., Otero, P., \& Hermida, E. (2014). La eficacia de la prevención indicada de la depresión: Una revisión. Anales de Psicologia, 30(1), 9-24. https://doi.org/10.6018/analesps.30.1.138931 Vesga-López, O., Blanco, C., Keyes, K., Olfson, M., Grant, B. F., \& Hasin, D. S. (2008). Psychiatric disorders in pregnant and postpartum women in the United States. Archives of General Psychiatry, 65(7), 805-815. https://doi.org/10.1001/archpsyc.65.7.805

Vliegen, N., Casalin, S., \& Luyten, P. (2014). The Course of Postpartum Depression. Harvard Review of Psychiatry, 22(1), 1-22. https://doi.org/10.1097/HRP.0000000000000013

Zayas, L. H., Jankowski, K. R. B., \& McKee, M. D. (2003). Prenatal and Postpartum Depression Among Low-Income Dominican and Puerto Rican Women. Hispanic Journal of Behavioral Sciences, 25(3), 370-385. https://doi.org/10.1177/0739986303256914 